\title{
Is CEO Pay Really Inefficient? A Survey of New Optimal Contracting Theories*
}

\author{
Alex Edmans \\ Wharton School, University of Pennsylvania, Philadelphia, PA 19104, USA \\ email: aedmans@wharton.upenn.edu \\ Xavier Gabaix \\ NYU Stern School of Business, New York, NY 10012, USA \\ email: xgabaix@stern.nyu.edu \\ (forthcoming in European Financial Management)
}

\begin{abstract}
Bebchuk and Fried (2004) argue that executive compensation is set by CEOs themselves rather than boards on behalf of shareholders, since many features of observed pay packages may appear inconsistent with standard optimal contracting theories. However, it may be that simple models do not capture several complexities of real-life settings. This article surveys recent theories that extend traditional frameworks to incorporate these dimensions, and show that the above features can be fully consistent with efficiency. For example, optimal contracting theories can explain the recent rapid increase in pay, the low level of incentives and their negative scaling with firm size, pay-for-luck, the widespread use of options (as opposed to stock), severance pay and debt compensation, and the insensitivity of incentives to risk.
\end{abstract}

Keywords: executive compensation; CEO incentives; optimal contracting.

JEL classification: $D 2, D 3, G 34, J 3$

${ }^{*}$ We thank an anonymous referee, Ingolf Dittmann and Ernst Maug for valued input. 


\section{Introduction}

CEO compensation is a controversial topic. In theory, pay packages should be designed by boards to maximize value on behalf of shareholders. Contracts should therefore attract talented CEOs and incentivize them to exert effort, exploit growth opportunities, and reject wasteful projects, while minimizing the cost of doing so. However, many empirical facts may appear inconsistent with optimal contracting. For example, CEO pay in the U.S. has risen substantially in recent years, vastly outpacing the rise in average wages. Moreover, CEO wealth appears to bear little relation to firm performance, especially in large firms. Other seemingly inefficient features include severance packages for failed CEOs, rewarding CEOs for luck, and the high level of stock options compared to shares.

In a thought-provoking book, Bebchuk and Fried (2004) argue that these facts are evidence that compensation is decided by executives themselves, who seek to maximize their own wealth rather than shareholder value. This view has proven highly influential and sparked calls for policy intervention (see, e.g., Kandel (2009) for proposals to improve the efficiency of pay) and major reforms in corporate governance more generally to increase shareholder power. It has also provided the motivation for new theories which model compensation as being set by the CEO rather than shareholders, such as Kuhnen and Zwiebel (2007) and Ruiz-Verdú (2008). ${ }^{1}$ However, Bebchuk and Fried's interpretation of the evidence has been challenged on both conceptual and empirical grounds. As an example of the former, Holmstrom (2005) points out that the rise in pay is only a recent phenomenon that has coincided with a decrease in CEO power resulting from greater institutional pressure. He also argues that compensation does not appear to be vastly different between family firms and dispersed corporations, even though managerial power varies significantly across the two settings. As an example of the latter, Core, Guay and Thomas (2005) argue that the sensitivity of CEO wealth to firm performance is substantially higher than the levels documented by Bebchuk and Fried, when taking into account the CEO's previously granted stock and options rather than just changes in annual salary. ${ }^{2}$

This article contributes to the above debate by challenging the rent extraction view on theoretical grounds. While the features highlighted by Bebchuk and Fried are inconsistent with the predictions of simple models, it may be that there are many complex aspects of the employment relationship not captured by traditional theories. A contract that accounts for these important dimensions may indeed contain the above aspects. We survey a number of recent models in the above spirit. Given space constraints, it is far from comprehensive and omits many important contributions to the field. In particular, it contains predominantly working papers and newly published papers in order to capture the most recent research, at the expense of many "classics."

We start in Section 2 by reviewing recent theories that seek to justify the apparently high level of pay, its low sensitivity to firm performance, and its high sensitivity to luck. Section 3 tackles the

\footnotetext{
${ }^{1}$ In both papers, the CEO is able to hide compensation from shareholders. The trade-off is that excessive hidden compensation reduces reported profits and may lead to shareholder intervention.

${ }^{2}$ Murphy (1999) and Core, Guay and Larcker (2003) also provide additional surveys and interpretations of the empirical evidence from Bebchuk and Fried (2004).
} 
composition of compensation contracts, such as the mix of stock, options and salary, and the use of severance pay and debt-like instruments. Section 4 addresses further cross-sectional determinants of pay, such as industry dynamics, as well as highlighting parameters that contracts need not depend upon. Section 5 concludes.

\section{The Level and Sensitivity of Pay}

\subsection{The Level of Pay}

The sheer magnitude of CEO pay is perhaps the most commonly cited statistic in support of the rent extraction view. For example, the 250th best-paid U.S. CEO earned $\$ 8.3$ million in 2004. This is substantially higher than in other countries and represents a six-fold increase since 1980.

To understand these trends, Gabaix and Landier (2008) analyze a simple equilibrium model of CEO pay. CEOs have different talents and are matched to firms in a competitive assignment model. The model contains no incentive problem, and so CEOs are paid for their talent, not as compensation for risk or effort. Since talent has greatest effect in bigger firms, in market equilibrium the most skilled CEOs are employed by the largest companies, and so a CEO's pay is increasing in the size of his firm. It is also increasing in aggregate firm size, since if companies become larger across the economy, the returns to employing talented managers rise and this competition bids up wages. They show that the six-fold increase in U.S. CEO pay since 1980 can be attributed to the simultaneous growth in firm size.

Rising competition for managerial talent may stem from other factors in addition to firm growth. Frydman (2005) and Murphy and Zabojnik (2007) provide theory and evidence documenting the increasing importance of transferable rather than firm-specific human capital for the CEO's job, which directly increases pay through expanding CEOs' outside options. Moreover, Giannetti (2008) documents an additional, more subtle channel. An increase in the possibility of job-switching (which may result from greater transferability of skills) induces CEOs to select short-term projects that increase their external marketability, rather than efficient long-term projects. To prevent such behavior, shareholders must promise the manager a greater share of the profits from a long-term project, which raises expected compensation. ${ }^{3}$ Cao and Wang (2008) present a market equilibrium model where firms and CEOs search for optimal matches. They show both theoretically and empirically that the growing performance of the macro-economy and firm specific factors simultaneously generate the rise in CEO pay and firm size. Marin and Verdier (2004) argue that an increase in international trade has led to foreign firms entering the war for managerial talent, which in turn puts upward pressure on pay.

Conversely, the increase in firm size can augment pay levels through channels unrelated to competition for talent. Gayle and Miller (forthcoming) show theoretically and empirically that larger

\footnotetext{
${ }^{3}$ Since fixed salaries cannot fall below zero owing to limited liability, shareholders cannot accompany the increased profit share with a reduction in cash to keep total pay constant.
} 
firms are more complex to manage, and so CEOs require greater pay as compensation. In addition, agency problems are greater in large firms, necessitating higher equity incentives and thus a salary increase as a premium for bearing risk. A number of other papers also point to the changing nature of the employment relationship. Hermalin (2005) argues that tighter corporate governance increases both the level of effort that the CEO must exert and the risk of dismissal, and so managers demand greater pay as compensation. In Garicano and Rossi-Hansberg (2006), CEOs specialize in knowledge acquisition and problem solving, leaving routine production tasks to lower-level employees. Recent increases in communication technologies (e.g. e-mail) allow even greater specialization, since CEOs can communicate their knowledge to subordinates to be used in production. This greater focus on skilled tasks also leads to an increase in CEO pay.

A quite separate explanation is offered by Hayes and Schaefer (forthcoming). They show that, if the market forms inferences about the CEO's productivity from his salary, firms may wish to inflate their pay to improve outsiders' perceptions and temporarily boost the stock price. This leads to a "Lake Wobegon Effect" - all firms wish to pay their CEO above the market average, thus increasing aggregate pay levels over time.

\subsection{Sensitivity to Own-Firm Performance}

A second major controversy is the apparent insensitivity of CEO wealth to performance. Jensen and Murphy (1990) documented that the CEO loses only $\$ 3.25$ for every $\$ 1,000$ decline in firm value, an effective equity stake of $0.3 \%$. Jensen and Murphy also found that "dollar-dollar" incentives (the dollar change in $\mathrm{CEO}$ wealth for a dollar change in firm value) decline strongly in firm size, a relationship confirmed by many subsequent studies. It seems not only that incentives are low on average, but they are particularly weak in the largest firms which are most important for the economy. Bebchuk and Fried (2004) interpret the negative scaling as evidence that governance is particularly weak in large firms, allowing managers to negotiate contracts with suboptimally low sensitivities.

By contrast, Haubrich's (1994) seminal calibration showed that Jensen and Murphy's findings need not be inconsistent with optimal contracting if the CEO is sufficiently risk-averse. Edmans, Gabaix and Landier (forthcoming) attempt to jointly explain both the level of CEO incentives and their scaling with firm size without requiring risk aversion. They posit that CEO effort has a percentage (i.e. multiplicative) effect on firm value, because most actions can be "rolled out" across the entire firm, and a percentage effect on CEO utility, so that leisure is a normal good. Therefore, for incentive compatibility, a firm value increase of $1 \%$ should generate a sufficient percentage increase in the CEO's wealth. This required percentage increase equals the marginal cost of effort and does not depend on firm size. The relevant measure of incentives is thus "percent-percent" incentives - the percentage change in CEO wealth for a percentage firm return - and is size-independent. In turn, dollar-dollar incentives equal percent-percent incentives multiplied by the CEO's wage and divided by firm size. This identity can reconcile both of the above facts. First, since firm size is substantially larger than the CEO's wage, it dollar-dollar incentives are inevitably low, exactly as found by Jensen and Murphy. 
Second, since empirically the wage has a $1 / 3$ elasticity with size ${ }^{4}$, dollar-dollar incentives should have a size elasticity of $1 / 3-1=-2 / 3$, quantitatively consistent with Edmans et al.'s empirical estimate of -0.60. Simply put, since CEO effort has such a strong effect in a large firm, a small equity stake is sufficient to deter shirking.

While the CEO is risk-neutral in Edmans et al., He (2008a) shows that risk aversion can qualitatively explain the negative relationship between incentives and size. The risk imposed by equity compensation is higher in a larger firm, thus diminishing the optimal equity level. Dicks's (2008) perspective is governance is more productive in large companies. Thus, the optimal level of monitoring is higher in such firms, reducing the need for monetary incentives. Gervais, Heaton and Odean (2008) show that managerial overconfidence can reduce the incentives required to induce a manager to undertake risky but profitable projects. A rational manager may turn down such projects since he has undiversified firm-specific human capital, but an overconfident manager overvalues such projects and thus will take them even with relatively low incentives.

An alternative justification of seemingly low incentives is that there are negative consequences of equity alignment, which an efficient contract must balance. In Benmelech, Kandel and Veronesi (2007), at some point the CEO privately observes that the firm has matured and its growth potential has diminished. The optimal action would be to disclose to the market that investment opportunities have declined, thus allowing him to efficiently reduce the level of investment. However, such a disclosure will reduce the stock price, and so a manager with a large equity stake may conceal the information and persist with the (now inefficient) high investment policy. ${ }^{5}$ In a similar vein, Peng and Roell (2008) and Goldman and Slezak (2006) demonstrate that high incentives can encourage the manager to expend firm resources to manipulate the stock price upwards. ${ }^{6}$ Acharya and Bisin (forthcoming) show that if a CEO can hedge the component of his equity compensation related to market risk but not idiosyncratic risk, he will favor projects which bear the former but not the latter. This in turn leads to excessive aggregate risk in the economy as a whole. As in the other theories, a reduction in pay-performance sensitivity is optimal to alleviate these perverse incentives.

\subsection{Sensitivity to Luck}

While CEOs are believed to be insufficiently punished for poor performance of their own firm, which is likely under their responsibility, an additional concern is that they are rewarded for general market upswings outside their responsibility, i.e. paid for luck (Bertrand and Mullainathan, 2001). This practice contradicts theories of compensation that advocate relative performance evaluation, such as Holmstrom (1982).

\footnotetext{
${ }^{4}$ See Gabaix and Landier (2008) for a survey of the empirical evidence.

${ }^{5}$ Their model provides a theoretical foundation for the "agency costs of overvalued equity" discussed in Jensen (2004).

${ }^{6}$ Bolton, Scheinkman and Xiong (2006) show that manipulation may sometimes benefit shareholders. In speculative markets where there are overoptimistic buyers, short-term manipulation allows current shareholders to sell the stock for a higher price to purchasers who overvalue the stock. Therefore, short vesting periods may be optimal, as observed empirically.
} 
There are a number of quite distinct rationalizations of pay-for-luck. Oyer (2004) posits that the CEO's outside opportunities are more attractive in broader market upswings. An increase in pay is therefore necessary to persuade him to stay with the firm.

Axelson and Baliga (forthcoming) consider the design of renegotiation-proof long-term contracts. To prevent interim renegotiation, the manager must have private information that causes him to have a different view from the board on the value of his long-term pay. Industry prospects are an example of such private information, and so it can be efficient to make the contract contingent upon them.

Gopalan, Milbourn and Song (2008) argue that the firm's exposure to sector movements is an important aspect of the CEO's strategic choice. Tying the CEO to industry performance induces him to choose this exposure optimally. Moreover, owing to risk aversion, the optimal contract will reward the manager for good sector performance but not punish him for bad luck.

Noe and Rebello (2008) jointly model CEO compensation and governance in a dynamic world, where the board learns firm quality over time. Even if high past performance is unrelated to CEO effort, it provides information about intrinsic firm quality and thus future cash flow generation potential. Stronger future prospects in turn raise the manager's marginal productivity and thus his optimal current compensation.

Danthine and Donaldson (2008) adopt a consumption-based equilibrium approach. For CEOs to maximize value on behalf of shareholders, they must evaluate projects using the same discount rate as shareholders. By tying pay to aggregate market conditions, the manager's consumption stream is perfectly correlated with shareholders, and so he uses the correct discount rate.

\section{The Structure of Pay}

\subsection{Stock versus Options}

While Section 2.2 tackles the slope of incentives, this section addresses their convexity. Most empirical measures of incentives consider the overall sensitivity of incentives of CEO wealth to firm value, but do not distinguish between incentives provided by stock as opposed to options. Similarly, theories based on effort alone derive the optimal contract as a general sensitivity to firm performance, and are ambivalent as to whether this is implemented using stock or options, i.e. whether contracts should be linear or convex. However, stock and options differ along two dimensions. Since options are riskier, $\$ 1$ of options is worth less to the CEO than $\$ 1$ of stock, rendering them more expensive to the firm. On the other hand, since $\$ 1$ of options provides greater incentives than $\$ 1$ of stock, this tends to make them cheaper. Dittmann and Maug (2007) calibrate the standard principal-agent model widely used in contract theory, where the CEO has exponential utility and makes only an effort decision. They find that the first effect is dominant, suggesting that the optimal contract should involve only stock and not options. Their empirical estimation shows that these predictions are strongly contradicted, giving rise to a puzzle. 
Bebchuk and Fried (2004) interpret the widespread use of options as rent extraction since at-themoney options did not have to be expensed until 2006, and so such compensation was only disclosed in footnotes where they are less visible to investors. However, a number of recent theories show that options can be rationalized with plausible extensions to the standard principal-agent model. Motivated by ample psychological evidence and its success in explaining a number of asset pricing puzzles, Dittmann, Maug and Spalt (2008) posit a loss averse utility function. If the CEO has a low reference wage, options now become part of the optimal contract. Owing to their asymmetric payoff structure, options limit the CEO's downside upon bad luck, and this insurance is particularly valuable to a loss averse agent. Hence, the optimal contract involves "carrots" (rewards for high performance), rather than "sticks" (punishment for poor performance), and the former are provided by convex instruments such as options.

Dittmann and $\mathrm{Yu}$ (2008) show that observed compensation structures can be rationalized even with exponential utility, if the CEO chooses firm risk in addition to effort, since options provide stronger risk-taking incentives. Armstrong, Larcker and $\mathrm{Su}$ (2007) find that options are part of the optimal contract when jointly endogenizing the target effort level in addition to the contract structure, with a lower bound on cash salary, and under the assumption that the market does not anticipate the compensation contract.

If options are indeed efficient, the optimal strike price then becomes an important question. As mentioned above, the widespread use of at-the-money options may suggest rent extraction; Bebchuk and Fried (2004) argue that out-of-the-money options should instead be used as they only pay off upon strong performance. Maug and Spalt (2008) calibrate the loss-averse model used by Dittmann, Maug and Spalt (2008) to justify stock options in the first instance and find that, in fact, almost as many firms should grant in-the-money as out-of-the-money options. Dittmann and Yu (2008) find that in-the-money options are optimal under exponential utility if the CEO can affect firm risk. Both papers find that the savings from switching from at-the-money options to options with optimal strike prices are very small, and so current practices are not significantly suboptimal.

\subsection{Severance Pay}

Severance pay has been a particularly controversial feature of compensation in the recent financial crisis. It is especially prevalent among dismissed CEOs compared to those who voluntarily retire (Yermack, 2006) and thus appears to reward CEOs for failure. It may therefore further exacerbate the weak incentives caused by low stock and option awards, as discussed in Section 2.2.

As with many of the other empirical puzzles, severance pay is difficult to rationalize with a standard principal-agent model where the CEO controls only effort, but can be justified by richer frameworks. Inderst and Mueller (2008) argue that severance pay can deter a CEO from entrenching himself by concealing negative information that would lead to his dismissal. Similarly, Almazan and Suarez (2003) show that, if the CEO is entrenched owing to a weak board, severance pay can encourage him to retire when a more able replacement is available. On the other hand, if the board is strong, the 
CEO may fail to exert effort with long-lasting consequences since he fears dismissal. Severance pay may then be optimal for a different reason: it solves the above time-inconsistency problem by ensuring that he earns a return on his effort.

Manso (2008) shows that, if an important aspect of the CEO's job is to explore new technologies rather than merely exploit existing ones, the optimal contract involves reward for failure. He (2008b) demonstrates that, if the CEO can privately save, he will undo any contract which involves front-loaded payments by saving high current consumption for the future. A contract robust to private savings must therefore involve a non-decreasing wage pattern over time. Severance pay achieves this structure by supporting his post-firing consumption at the current wage level. In Heen (2008), non-compete agreements reduce a departing CEO's labor market opportunities, and so the optimal contract contains severance pay as compensation. Heen's empirical results support the view that severance pay results from non-compete agreements, rather than rent extraction.

\subsection{Debt}

While the majority of compensation research has focused on stock and options, recent empirical studies (Bebchuk and Jackson, 2005; Sundaram and Yermack, 2007; Gerakos, 2007) have found that U.S. CEOs hold substantial defined benefit pensions. These are unsecured obligations which yield an equal claim with other creditors in bankruptcy, and thus constitute inside debt. ${ }^{7}$ Empiricists have also noted the widespread use of deferred compensation, another form of inside debt, although systematic studies have so far been limited by data availability. ${ }^{8}$ Since the vast majority of theories advocate only equity-like instruments, Bebchuk and Jackson argue that inside debt represents hidden compensation, particularly since disclosure requirements were limited until recently.

Edmans (2008) justifies inside debt as an efficient deterrent to risk-shifting. Previously proposed remedies include bonuses for achieving solvency, or salaries and private benefits that are forfeited in bankruptcy. These instruments are sensitive to the incidence of bankruptcy, but if bankruptcy occurs, they pay zero regardless of liquidation value. By contrast, inside debt yields a positive payoff in bankruptcy, proportional to the recovery value. Thus it renders the manager sensitive to firm value in bankruptcy, and not just the incidence of bankruptcy - exactly as desired by creditors. Indeed, debt-aligned managers reduce firm risk, as measured by the firm's distance to default (Sundaram and Yermack, 2007) or its credit rating (Gerakos, 2007). Inside debt can thus reduce the cost of raising external debt, to the benefit of shareholders.

\footnotetext{
7 "Inside" debt refers to debt owned by the manager, rather than external investors.

${ }^{8}$ Despite limited data, anecdotal evidence suggests that such compensation may be substantial. For example, Roberto Goizueta, the former CEO of Coca-Cola, had over $\$ 1$ billion in deferred compensation when he died.
} 


\section{Cross-Sectional Determinants of Pay}

\subsection{Industry Dynamics}

Empirical predictions for the cross-sectional determinants of pay can be generated by embedding the principal-agent problem into a market equilibrium. Section 2 discussed how incorporating the competitive labor market yields relationships with firm size. An alternative equilibrium approach is to analyze the firm within the context of a competitive industry, thus generating comparative statics for the effect of product market competition.

Falato and Kadyrzhanova (2008) show that incentives are optimally lower among industry leaders, since they have fewer growth opportunities than laggards and so the benefits of effort are smaller. Moreover, in industries where market share is evenly distributed across firms, competition is particularly fierce. This leads to large gains from effort and thus high optimal incentives.

Baranchuk, MacDonald and Yang (2008) introduce product market competition to endogenize firm size. If industry demand increases, large firms gain disproportionately, increasing the skewness of size and thus the skewness of pay. A rise in demand also increases the level of through two channels. It augments profits, which firms compete away to retain managerial talent. It also raises the optimal level of effort, necessitating higher pay as compensation. Since industry demand is outside the manager's control, the paper offers an additional justification for "pay-for-luck" to those in Section 2.3.

\subsection{What Need Not Matter For Executive Compensation?}

While the above subsection addresses parameters that do affect optimal compensation policy, it is also interesting to understand which factors need not matter. Grossman and Hart (1983) show that, even in simple settings, the optimal contract is highly complex. It typically cannot be solved for in closed form and is contingent upon many specific features of the contracting situation, such as the agent's utility function and noise distribution. This dependence presents challenges for real-life contract designers, such as boards, since the above parameters are difficult for them to measure and thus use to guide the optimal contract.

Edmans and Gabaix (2008) demonstrate that, in a broad class of situations, these details need not matter: the contract is "detail-neutral." They first fix the target effort level and solve for the cheapest contract that implements it. The efficient incentive slope is attainable in closed form and independent of the noise distribution. Moreover, if the cost of effort can be expressed in monetary terms (e.g. it represents an opportunity cost of working elsewhere), the contract is linear - regardless of the CEO's utility function. The framework thus extends the tractable contracts of Holmstrom and Milgrom (1987) to settings that do not require exponential utility, Gaussian noise nor continuous time. Next, they endogenize the target effort level that the principal wishes to implement and shows that it may also be detail-neutral. In standard models, the effort level results from a trade-off between its positive effect on firm value and the direct disutility of effort plus the risk imposed by incentives required to 
induce effort. If the firm is sufficiently large, the benefits of effort (which are proportional to firm size) swamp the costs (which are proportional to CEO pay), and so maximum effort is always optimal the "maximum effort principle". Therefore, firm risk and the CEO's risk aversion matter neither for the optimal effort level nor the efficient contract to implement this effort level. The irrelevance of firm risk is consistent with the empirical evidence surveyed by Prendergast (2002): a number of studies

find that incentives are not significantly related to risk, with the remainder equally divided between finding positive and negative correlations.

\section{Conclusion}

A number of features of observed compensation schemes appear to be inconsistent with optimal contracting, and are thus frequently interpreted as evidence of rent extraction. Such views in turn lead to calls for policymakers to intervene and regulate executive pay. This article has surveyed a number of recent theories which reach a different conclusion. By incorporating complex, but realistic, aspects of the employment relationship, these above features can be reconciled with efficient paysetting.

That an empirical finding is consistent with an optimal contracting model does not rule out the possibility that it results from rent extraction. Most stylized facts in economics have multiple explanations, and further research is necessary to evaluate the competing hypotheses. In addition, even if compensation is efficient on average, it does not preclude pay schemes being suboptimal in particular firms, and so intense scrutiny (by shareholders or boards) remains important. Moreover, there are a number of puzzles as yet unexplained by optimal contracting theories. Why was backdating of stock options so prevalent? Why is a significant proportion of compensation in hidden forms such as perks? Why does the stock market sometimes react positively to the death of an allegedly optimally contracted CEO? These are ripe questions for future research. The purpose of this article, and of the theories it surveys, is not to claim that compensation is definitely efficient, but to highlight the two-sided nature of the issue and the need for further research to draw clearer conclusions. As with all interesting debates, we expect this one will continue for some time. 


\section{References}

Acharya, V. and Bisin, A., 'Managerial hedging, equity ownership, and firm value', RAND Journal of Economics, forthcoming.

Almazan, A. and Suarez J., 'Entrenchment and severance pay in optimal governance structures', Journal of Finance, Vol. 58, 2003, pp. 519-548.

Armstrong, C., Larcker, D. and Su, C., 'Stock options and Chief Executive Officer compensation', Working paper (University of Pennsylvania, 2007).

Axelson, U. and Baliga S., 'Liquidity and manipulation of executive compensation schemes', Review of Financial Studies, forthcoming.

Baranchuk, N., MacDonald C. and Yang, J. 'The economics of super managers', Working paper (University of Texas at Dallas, 2008).

Bebchuk, L. and Fried, J., Pay Without Performance: The Unfulfilled Promise of Executive Compensation (Cambridge: Harvard University Press, 2004).

Bebchuk, L. and Jackson, R., 'Executive pensions', Journal of Corporation Law, Vol. 30, 2005, pp. 823-855.

Benmelech, E., Kandel, E. and Veronesi, P., 'Stock-based compensation and CEO (dis)incentives', Working paper (Harvard University, 2007).

Bertrand, M. and Mullainathan S., 'Are CEOs rewarded for luck? The ones without principals are', Quarterly Journal of Economics, Vol. 116, 2001, pp. 901-932.

Bolton, P., Scheinkman, J. and Xiong, W., 'Executive compensation and short-termist behaviour in speculative markets', Review of Economic Studies, Vol. 73, 2006, pp. 577-610.

Cao, M. and Wang R., 'Search for optimal CEO compensation: theory and empirical evidence', Working paper (York University, 2008).

Core, J. Guay, W. and Larcker, D., 'Executive equity compensation and incentives: a survey', Federal Reserve Bank of New York Economic Policy Review, Vol. 9, 2003.

Core, J., Guay, W. and Thomas, R., 'Is U.S. CEO compensation inefficient pay without performance?', Michigan Law Review, Vol. 103, 2005, pp. 1142-1185.

Danthine, J. and Donaldson J., 'Executive compensation: a general equilibrium perspective', Working paper (University of Lausanne, 2008).

Dicks, D., 'Executive compensation, incentives, and the role for corporate governance regulation', Working paper (University of North Carolina, 2008).

Dittmann, I. and Maug, E., 'Lower salaries and no options? On the optimal structure of executive pay', Journal of Finance, Vol. 62, 2007, pp. 303-343.

Dittmann, I. Maug, E. and Spalt, O., 'Sticks or carrots? Optimal CEO compensation when nanagers are loss-averse', Working paper (Erasmus University Rotterdam, 2008).

Dittmann, I. and Yu, K., 'How important are risk-taking incentives in executive compensation? Evidence from model calibrations for U.S. CEOs', Working paper (Erasmus University Rotterdam, 2008). 
Edmans, A., 'Inside debt', Working paper (University of Pennsylvania, 2008).

Edmans, A. and Gabaix, X., 'Tractability and detail-neutrality in incentive contracting', Working paper (University of Pennsylvania, 2008).

Edmans, A., Gabaix, X. and Landier, A., 'A multiplicative model of optimal CEO incentives in market equilibrium', Review of Financial Studies, forthcoming.

Falato, A., and Kadyrzhanova, D., "Optimal CEO incentives and industry dynamics', Working paper (Federal Reserve Board, 2008).

Frydman, C., 'Rising through the ranks: the evolution of the market for corporate executives, 1936-2003', Working paper (Massachusetts Institute of Technology, 2005).

Gabaix, X. and Landier, A., 'Why has CEO pay increased so much?', Quarterly Journal of Economics, Vol. 123, 2008, pp. 49-100.

Garicano, L. and Rossi-Hansberg, E., 'Organization and inequality in a knowledge economy', Quarterly Journal of Economics, Vol. 71, 2006, pp. 1383-1435.

Gayle, G. and Miller, R., 'Has moral hazard become a more important factor in managerial compensation?', American Economic Review, forthcoming.

Gerakos, J. 'CEO pensions: disclosure, managerial power, and optimal contracting', Working paper (University of Chicago, 2007).

Gervais, S., Heaton, J.B. and Odean, T., 'Overconfidence, investment policy, and manager welfare', Working paper (Duke University, 2007).

Giannetti, M., 'Serial CEO incentives and the structure of managerial contracts', Working paper (Stockholm School of Economics, 2008).

Goldman, E. and Slezak, S., 'An equilibrium model of incentive contracts in the presence of information manipulation', Journal of Financial Economics, Vol. 80, 2006, pp. 603-626.

Gopalan, R. Milbourn, T. and Song, F., 'Strategic flexibility and the optimality of pay for luck', Working paper (Washington University in St. Louis, 2008).

Grossman, S. and Hart, O., 'An analysis of the principal-agent problem', Econometrica, Vol. 51, 1983, pp. 7-45.

Haubrich, J., 'Risk aversion, performance pay, and the principal-agent problem', Journal of Political Economy, Vol. 102, 1994, pp. 258-275.

Hayes, R. and Schaefer, S., 'CEO pay and the Lake Wobegon effect," Journal of Financial Economics, forthcoming.

He, Z., 'Agency problems, firm valuation, and capital structure', Working paper (University of Chicago, 2008a).

He, Z., 'Dynamic compensation contracts with private savings', Working paper (University of Chicago, 2008b).

Heen, K., "Non-compete agreements: the real cause of severance pay?', Working paper (Swedish Institute for Financial Research, 2008).

Hermalin, B., 'Trends in corporate governance', Journal of Finance, Vol. 60, 2005, pp. 2351-2384. 
Holmstrom, B., 'Moral hazard in yeams', Bell Journal of Economics, Vol. 13, 1982, pp. 324-340.

Holmstrom, B., 'Pay without performance and the managerial power hypothesis: a comment', Journal of Corporation Law, Vol. 30, 2005, pp. 703-715.

Holmstrom, B. and Milgrom, P., 'Aggregation and linearity in the provision of intertemporal incentives', Econometrica, Vol. 55, 1987, pp. 308-328.

Inderst, R. and Mueller, H., 'CEO replacement under private information." Working paper (London School of Economics, 2008).

Jensen, M., 'The agency costs of overvalued equity and the current state of corporate finance', European Financial Management, Vol. 10, 2004, pp. 549-565.

Jensen, M. and Murphy, K. J., 'Performance pay and top-management incentives', Journal of Political Economy, Vol. 98, 1990, pp. 225-64.

Kandel, E., 'In search of reasonable executive compensation', CESifo Economic Studies, forthcoming.

Kuhnen, C. and Zwiebel, J., 'Executive pay, hidden compensation and managerial entrenchment', Working paper (Northwestern University, 2007).

Manso, G., 'Motivating innovation', Working paper (Massachusetts Institute of Technology 2008).

Marin, D. and Verdier, T., 'Globalization and the empowerment of talent', CEPR Discussion Paper, No. 4129, 2004.

Maug, E. and Spalt, O., 'The optimal design of stock options: a loss-aversion approach', Working paper (University of Mannheim, 2008).

Murphy, K., 'Executive compensation', in O. Ashenfelter and D. Card (eds), Handbook of Labor Economics (New York: Elsevier/North-Holland, 1999).

Murphy, K. and Zabojnik, J., 'Managerial capital and the market for CEOs', Working paper (University of Southern California, 2007).

Noe, T. and Rebello, M., 'To each according to her luck and power: optimal corporate governance and compensation policy in a dynamic world', Working paper (University of Oxford, 2008).

Oyer, P., 'Why do firms use incentives that have no incentive effects?' Journal of Finance, Vol. 59, 2004, pp. 1619-1649.

Peng, L. and Roell, A., 'Manipulation and equity-based compensation', American Economic Review, Vol. 98, 2008, pp. 285-290.

Prendergast, C., 'The tenuous trade-off between risk and incentives', Journal of Political Economy, Vol. 110, 2002, pp. 1071-1102.

Ruiz-Verdú, P., 'Corporate governance when managers set their own pay', European Financial Management, Vol. 14, 2008, pp. 921-943.

Sundaram, R. and Yermack, D., 'Pay me later: inside debt and its role in managerial compensation', Journal of Finance, Vol. 67, 2007, pp. 1551-1588.

Yermack, D., 'Golden handshakes: separation pay for retired and dismissed CEOs', Journal of Accounting and Economics, Vol. 41, 2006, pp. 237-256. 